\title{
Tomato yellow leaf curl virus in the Dominican Republic: Characterization of an Infectious Clone, Virus Monitoring in Whiteflies, and Identification of Reservoir Hosts
}

\author{
Raquel Salati, Medhat K. Nahkla, Maria R. Rojas, Pablo Guzman, Jose Jaquez, \\ Douglas P. Maxwell, and Robert L. Gilbertson
}

\begin{abstract}
First, third, and seventh authors: Department of Plant Pathology, University of California, Davis 95616; second and sixth authors: Department of Plant Pathology, University of Wisconsin, Madison 53706; fourth author: California Crop Improvement Association, Parson Seed Certification Center, University of California, Davis 95616; and fifth author: Transagricola S.A., Santiago, Dominican Republic. Accepted for publication 14 January 2002.
\end{abstract}

\begin{abstract}
Salati, R., Nahkla, M. K., Rojas, M. R., Guzman, P., Jaquez, J., Maxwell, D. P., and Gilbertson, R. L. 2002. Tomato yellow leaf curl virus in the Dominican Republic: Characterization of an infectious clone, virus monitoring in whiteflies, and identification of reservoir hosts. Phytopathology 92:487-496.

Epidemics of tomato yellow leaf curl disease (TYLCD) in the Dominican Republic in the early to mid-1990s resulted in catastrophic losses to processing tomato production. As part of an integrated management approach to TYLCD, the complete nucleotide sequence of a fulllength infectious clone of an isolate of Tomato yellow leaf curl virus (TYLCV) from the Dominican Republic (TYLCV-[DO]) was determined. The TYLCV-[DO] genome was nearly identical in sequence $(>97 \%)$ and genome organization to TYLCV isolates from Israel and Cuba. This

from the eastern Mediterranean. A reduction in the incidence of TYLCV in the northern and southern processing tomato production areas of the Dominican Republic has been associated with the implementation of a mandatory 3-month whitefly host-free period (including tomato, common bean, cucurbits, eggplant, and pepper). Monitoring TYLCV levels in whiteflies, by polymerase chain reaction with TYLCV-specific primers, established that the incidence of TYLCV decreased markedly during the host-free period, and then gradually increased during the tomato-growing season. In contrast, TYLCV persisted in whiteflies and tomato plants in an area in which the host-free period was not implemented. Surveys for TYLCV reservoir hosts, conducted to identify where TYLCV persists during the host-free period, revealed symptomless infections in a number of weed species. The implications of these findings for TYLCV management in the Dominican Republic are discussed.
\end{abstract} established that TYLCV-[DO] is a bonafide TYLCV isolate (rather than a recombinant virus, such as isolates from Israel [Mild], Portugal, Japan, and Iran), and provided further evidence for the introduction of the virus

Tomato yellow leaf curl disease (TYLCD) is one of the most damaging diseases of tomato worldwide. Yield losses of $100 \%$ are common, particularly when plants are infected early in development $(5,25)$. TYLCD is caused by Tomato yellow leaf curl virus (TYLCV), which is transmitted in a persistent manner by the sweet potato whitefly (Bemisia tabaci Gennadius) (5,25). Infected plants show stunted and erect or upright growth and leaves curl upward and develop crumpling and distinctive interveinal chlorosis. TYLCD was first described in Israel in 1931 and has now been reported from many countries around the Mediterranean Basin and Africa $(5,25)$. In the middle to early 1990s, TYLCV was identified in the Dominican Republic $(16,26,37,38,40)$ and subsequently in Jamaica (22) and Cuba (41). More recently, TYLCV has been identified in Florida, Georgia, and Louisiana in the United States $(24,39,49)$, the Bahamas (47), Puerto Rico (4), and in the Yucatan Peninsula of Mexico (2).

TYLCV is a member of the genus Begomovirus of the family Geminiviridae (single-stranded [ss]DNA viruses with twinned icosahedral virions). Most begomoviruses possess a bipartite genome, composed of two approximately $2.6-\mathrm{kb}$ DNA components (17). TYLCV is unusual in that it has a monopartite genome, composed of a single genomic DNA component of approximately

Corresponding author: R. L. Gilbertson; E-mail address: rlgilbertson@ucdavis.edu

Publication no. P-2002-0311-01R

(C) 2002 The American Phytopathological Society
Additional keywords: begomovirus, Bemisia tabaci, whitefly-transmitted geminivirus.

$2.8 \mathrm{~kb}(17,30)$. Analyses of the complete nucleotide (nt) sequences of monopartite TYLCV isolates have revealed a common genome organization, with six open reading frames (ORFs) encoding proteins approximately $10 \mathrm{kDa}$ or greater $(1,20,30,32)$. ORFs V1 and V2 (encoding the coat protein [CP]), are in the viral sense and overlap, whereas the other four ORFs, C1 (encoding the replication-associated protein $[\mathrm{Rep}]), \mathrm{C} 2, \mathrm{C} 3$, and $\mathrm{C} 4$, are in the complementary sense and also overlap. An approximately 300-nt intergenic region (IR) contains the origin (ori) of replication, which includes a potential stem-loop structure that is involved in the rolling-circle replication of viral ssDNA $(17,21)$.

To better understand the nature of TYLCD in the Dominican Republic, the complete nucleotide sequence of an infectious TYLCV from the Dominican Republic (TYLCV-[DO]) clone was determined. Analysis of the TYLCV-[DO] sequence revealed that it is a bonafide TYLCV isolate, rather than a recombinant virus, and provided further evidence that the virus was introduced into the Caribbean from the eastern Mediterranean. The epidemiology of TYLCV-[DO] in the Dominican Republic was investigated to determine (i) the efficacy of a whitefly host-free period in reducing the incidence of TYLCV, and (ii) the identity of potential TYLCV reservoir hosts. These results are discussed in terms of management of TYLCV in the Dominican Republic.

\section{MATERIALS AND METHODS}

Full-length clone. The overlapping primer method (35) was used for polymerase chain reaction (PCR) amplification of a puta- 
tive full-length TYLCV DNA fragment. Primers PTYC1v2182 and PTYC1c2140, which overlap an NcoI site in the C1 ORF of TYLCV, and a DNA extract prepared from tomato leaf tissue showing TYLCD symptoms collected from Bani, Dominican Republic in 1994, were used in the PCR as previously described (26). PCR-amplified DNA fragments were digested with NcoI and ligated into NcoI-digested pGEM-5Zf+ (Promega Corp., Madison, WI). Recombinant plasmids were identified by restriction enzyme digestion analysis. The recombinant plasmid pTY-DR1, which contained the approximately 2.8 -kb full-length TYLCV clone, was selected for further characterization.

Inoculation of plants with cloned viral DNA. Tomato seedlings were inoculated with cloned viral DNA by particle bombardment as previously described $(11,14)$. Seven-day-old tomato seedlings (cvs. Floradade or Geneva 80) were bombarded with gold particles coated with TYLCV DNA (monomer excised from pTYDR1) or gold particles alone (negative control). Bombarded seedlings were planted in soil in a growth chamber maintained at $26^{\circ} \mathrm{C}$ for a 14-h light period and at $21^{\circ} \mathrm{C}$ for a 10 -h dark period. Plants were visually examined for development of disease symptoms up to 8 weeks postbombardment. In some cases, shoots (scions) from bombarded plants were grafted onto uninfected plants (stocks).

DNA sequencing and sequence analysis of infectious clone. The complete nucleotide sequence of the full-length TYLCV clone in pTY-DR1 was determined using the dideoxy chain termination method and Sequenase (USB, Cleveland, OH). DNA sequences were assembled and analyzed using the software of the Genetics Computer Group, University of Wisconsin, Madison (10). The GenBank accession numbers of sequences used for comparisons are as follows: AJ223505, TYLCV from Cuba (TYLCV-[CU]); X15656, TYLCV; AJ132711, TYLCV from Iran (TYLCV-[IR]); AF105975, TYLCV from Portugal (TYLCV[PT]); AB014346, TYLCV from Shizuokua, Japan (TYLCV[Shi]); X76319, a mild isolate of TYLCV from Israel (TYLCVMld); X61153, Tomato yellow leaf curl Sardinia virus (TYLCSV); Z25751, TYLCSV from Murcia, Spain (TYLCSV-ES[1]); L27708, TYLCSV from Almeria, Spain (TYLCSV-ES[2]); X63015, DNAA of a bipartite TYLCV from Thailand (TYLCTHV); U15016, a mild isolate of Tomato leaf curl virus from New Delhi, India (ToLCNdV-Mld); S53251, Tomato leaf curl virus (TLCV) from Australia; L14460, DNA-A of Tomato mottle virus (ToMoV); K02029, DNA-A of Tomato golden mosaic virus (TGMV);

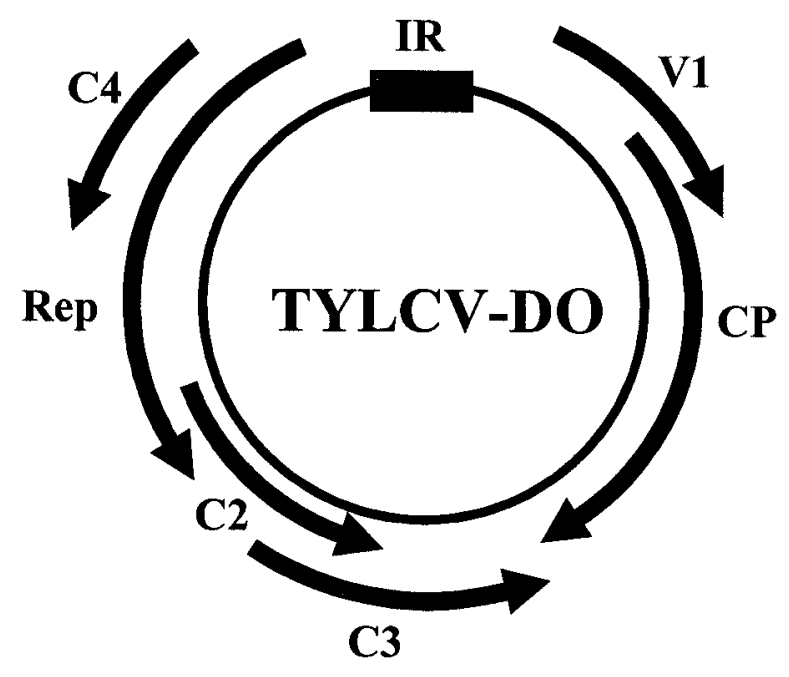

Fig. 1. Genome organization of an isolate of Tomato yellow leaf curl virus from the Dominican Republic (TYLCV-[DO]). Open reading frames (ORFs) are shown as black arrows; V denotes ORFs on the virion strand, and $\mathrm{C}$ denotes ORFs on the complementary strand. IR indicates the intergenic region, $\mathrm{CP}$ indicates the coat protein gene, and Rep indicates the replicationassociated protein gene.
AF101476, DNA-A of Tomato leaf crumple virus (TLCrV); X17095, DNA-A of African cassava mosaic virus (ACMV); and M24597, Beet curly top virus (BCTV).

Squash blot hybridization analysis. Leaf disks were squashed onto Nytran+ membranes using a glass rod, and membranes were prepared for hybridization as previously described (14). Membranes were hybridized with pTY-DR1 $(\approx 1.2 \mu \mathrm{g})$, labeled with $\left[\alpha^{32} \mathrm{P}\right]-\mathrm{dCTP}$ by nick translation (Prime-a-Gene Labeling System, Promega Corp.; or Nick Translation System, BRL, Gaithersburg, MD), under high stringency conditions (15). Most samples were squashed onto membranes in the Dominican Republic. Positive controls were leaf disks from tomato leaves with TYLCD symptoms collected from the field (when sampling was done during the tomato growing season) or that had been stored at $-80^{\circ} \mathrm{C}$ at the University of California (UC) Davis (when sampling was done during the host-free period). Leaf disks from uninfected greenhouse-grown tomato were used as negative controls, and these were squashed onto membranes at UC Davis. The following rating system was used to assess the relative intensity of the hybridization signals: $0=$ no signal, $1=$ weak signal, $2=$ moderate signal, 3 = strong signal, and $4=$ very strong signal.

Preparation of extracts from whiteflies and leaf tissue for PCR detection of TYLCV. Extracts from whiteflies for PCR analysis were prepared essentially as described by Mehta et al. (23). Whiteflies (approximately 30 adult whiteflies per sample) were received from the Dominican Republic in alcohol in screwcapped glass test tubes, and were transferred with Pasteur pipettes into $1.5-\mathrm{ml}$ microcentrifuge tubes. Tubes were centrifuged for $30 \mathrm{~s}$ at $14,000 \times g$ and the alcohol was removed. Whiteflies were washed with $500 \mu \mathrm{l}$ of STE buffer $(0.1 \mathrm{M} \mathrm{NaCl} ; 10 \mathrm{mM}$ Tris- $\mathrm{HCl}$, $\mathrm{pH} 8.0$; and $1 \mathrm{mM}$ EDTA) and centrifuged for $5 \mathrm{~min}$ at $14,000 \times$ $g$, after which the buffer was removed. STE buffer $(100 \mu \mathrm{l})$ was added and the whiteflies were ground with a plastic pestle (Kontes, Vineland, NJ). The tubes were centrifuged for $10 \mathrm{~min}$ at $14,000 \times g$, and $20 \mu \mathrm{l}$ of this whitefly extract was used in a $100-\mu \mathrm{l}$ reaction mixture. DNA was extracted from leaf tissue for PCR analysis as described by Dellaporta et al. (9). In most cases, $50 \mu \mathrm{l}$ of DNA extract was used in a $100-\mu 1$ reaction mixture.

PCR parameters used to amplify TYLCV DNA fragments were as previously described (43). For detection of TYLCV in tomato plants inoculated by particle bombardment, the TYLCV primer pair PTYC1v1707/PTYIRc4 (27), the degenerate primer pair PAL1v1978/PAR1c715 (43), or both were used. For detection of TYLCV in whiteflies and reservoir hosts, a TYLCV primer pair designed from the sequence of the $3^{\prime}$ portion of the CP gene was used (PTYv787, viral 5'-GTTCGATAATGAGCCCAG-3' and PTYc1121, complementary 5'-ATGTAACAGAAACTCATG-3'). These primers direct the amplification of a 334-bp TYLCV CP DNA fragment. For reservoir hosts, extracts from which the TYLCV CP fragment was not detected were tested for PCR inhibitors by repeating the PCR in the presence of $180 \mathrm{ng}$ of pTYDR1.

Southern blot hybridization analysis. DNA was fractionated in $1 \%$ Tris-borate-EDTA (TBE) agarose gels and transferred to Nytran+ membranes. Blots were hybridized under high stringency conditions with pTY-DR1 $(\approx 1.2 \mu \mathrm{g})$ labeled with $\left[\alpha^{32} \mathrm{P}\right]$-dCTP by nick-translation.

\section{RESULTS}

Infectivity of the full-length TYLCV-[DO] clone. Of 50 tomato seedlings (cv. Floradade) bombarded with the full-length TYLCV-[DO] monomer (from pTY-DR1), 16 developed leaf mottling and chlorosis symptoms approximately 40 days postinoculation (dpi). Control seedlings bombarded with gold particles alone did not develop symptoms. TYLCV DNA was detected in leaves of symptomatic plants by squash blot hybridization and PCR analyses. In a second experiment, 9 out of 50 seedlings (cv. 
Geneva 80) developed symptoms that were similar to those observed in inoculated seedlings in the first experiment. TYLCV DNA also was detected in leaves of these seedlings by squash blot and PCR analyses. When scions from infected cv. Geneva 80 plants were grafted onto uninfected cv. Floradade plants, typical TYLCD symptoms developed in newly emerging leaves approximately 3 weeks after grafting. The delayed and mild symptoms that developed in seedlings bombarded with the cloned TYLCV[DO] DNA may reflect the relative inefficiency of this inoculation method for the phloem-limited TYLCV (44). Alternatively, the clone may have a defect that is "corrected" during the systemic infection process, as was reported for a clone of an isolate of TYLCSV from Sicily (33).

Comparison of TYLCV-[DO] nucleotide and amino acid sequence with those of other geminiviruses. The TYLCV-[DO] genome consists of 2,781 nt (GenBank Accession No. AF024715). Consistent with current guidelines for presenting geminivirus sequences, the "A" residue (underlined) of the nicking site (arrow) within the conserved nanonucleotide sequence $\left(5^{\prime}\right.$-TAATATT ${ }^{\downarrow}$ AC$\left.3^{\prime}\right)$ of the stem-loop structure in the ori was designated as nucleotide 1 . Six ORFs encoding putative proteins approximately $10 \mathrm{kDa}$ or greater were identified (Fig. 1), and these corresponded to ORFs previously identified for other monopartite TYLCV and TYLCSV isolates. The nucleotide sequence identities and amino acid (aa) similarities of the TYLCV-[DO] ORFs and IR and those of other geminiviruses are shown in Table 1. Regardless of the sequence examined, TYLCV-[DO] was nearly identical to TYLCV[CU] (>99\% identity) and TYLCV (>97\% identity). The most notable difference between the TYLCV-[DO] (and TYLCV-[CU]) and TYLCV sequences was in the $3^{\prime}$ portion of the CP gene. Here, TYLCV has a 6-nt insertion (encoding isoleucine [I] and phenylalanine $[\mathrm{F}]$ residues) and 7-nt differences flanking this insertion. This results in the so-called FIFI motif in the predicted TYLCV $\mathrm{CP}$ amino acid sequence. However, resequencing of this region in the original TYLCV clone in the recombinant plasmid pTH20 (30) (provided by H. Czosnek) revealed that it was identical to those of other TYLCV isolates, including TYLCV-[DO]. Therefore, the consensus $\mathrm{CP}$ sequence was used for the comparisons made in this study.
There were $14 \mathrm{nt}$ and 7 aa differences between the TYLCV[DO] and TYLCV-[CU] sequences, whereas there were $47 \mathrm{nt}$ and 19 aa differences between TYLCV-[DO] and TYLCV and $46 \mathrm{nt}$ and 18 aa differences between TYLCV-[CU] and TYLCV. Most of the differences between TYLCV-[DO]/TYLCV-[CU] and TYLCV were shared (i.e., 38 of the $47 / 46$ nt differences [ $\approx 82 \%$ ], and 15 of the $19 / 18$ aa differences $[\approx 81 \%]$ ). Thus, these two Caribbean TYLCV isolates were more similar to each other than to TYLCV.

When the TYLCV-[DO] sequence was compared with those of TYLCV-Mld, TYLCV-[PT], TYLCV-[Shi], and TYLCV-[IR], the $\mathrm{CP}, \mathrm{V} 1, \mathrm{C} 2$, and $\mathrm{C} 3 \mathrm{ORF}$ sequences were nearly identical (i.e., $>96 \%$ identity) (Table 1). In contrast, the identities between the TYLCV-[DO] C1 and C4 ORF and IR sequences and those of these other TYLCV isolates were considerably lower (Table 1). Examination of the $\mathrm{C} 1 \mathrm{ORF}$ comparisons revealed that the $5^{\prime}$ portion was divergent, whereas the $3^{\prime}$ portion was highly conserved among these isolates (data not shown). Similarly, examination of the IR comparisons revealed that the $5^{\prime}$ portion was highly divergent, whereas the $3^{\prime}$ portion was highly conserved. Moreover, the transition from divergent to conserved sequences in the IR occurred in the stem-loop sequence (data not shown). These results suggest that (i) the TYLCV-Mld, TYLCV-[PT], TYLCV[Shi], and TYLCV-[IR] are recombinant viruses having genomes composed of TYLCV sequences (CP, V1, C2, and C3 ORFs and portions of the $\mathrm{C} 1 \mathrm{ORF}$ and IR) and sequences from another begomovirus or begomoviruses (C4 ORF and portions of the $\mathrm{C} 1$ ORF and IR) and (ii) that the recombination sites are in the $5^{\prime}$ portion of the $\mathrm{C} 1 \mathrm{ORF}$ and in the stem-loop sequence of the IR.

Comparisons made with the non-TYLCV sequences of the recombinant TYLCV isolates revealed a high degree of identity among TYLCV-Mld, TYLCV-[PT], and TYLCV-[Shi] sequences (e.g., $99 \%$ nucleotide identity and $98 \%$ amino acid similarity for the C4 ORF), but considerably lower identities with TYLCV-[IR] (e.g., 69 to $70 \%$ nucleotide identity and 46 to $47 \%$ amino acid similarity for the C4 ORF). Thus, TYLCV-Mld, TYLCV-[PT], and TYLCV-[Shi] appear to be isolates of the same recombinant virus, whereas TYLCV-[IR] is a different recombinant begomovirus.

TABLE 1. Percent nucleotide (nt) identities and derived amino acid (aa) similarities between open reading frames (ORFs) and the intergenic region (IR) of Tomato yellow leaf curl virus from Dominican Republic (TYLCV-[DO]) and those of other TYLCV isolates and geminivirus species ${ }^{\mathrm{a}}$

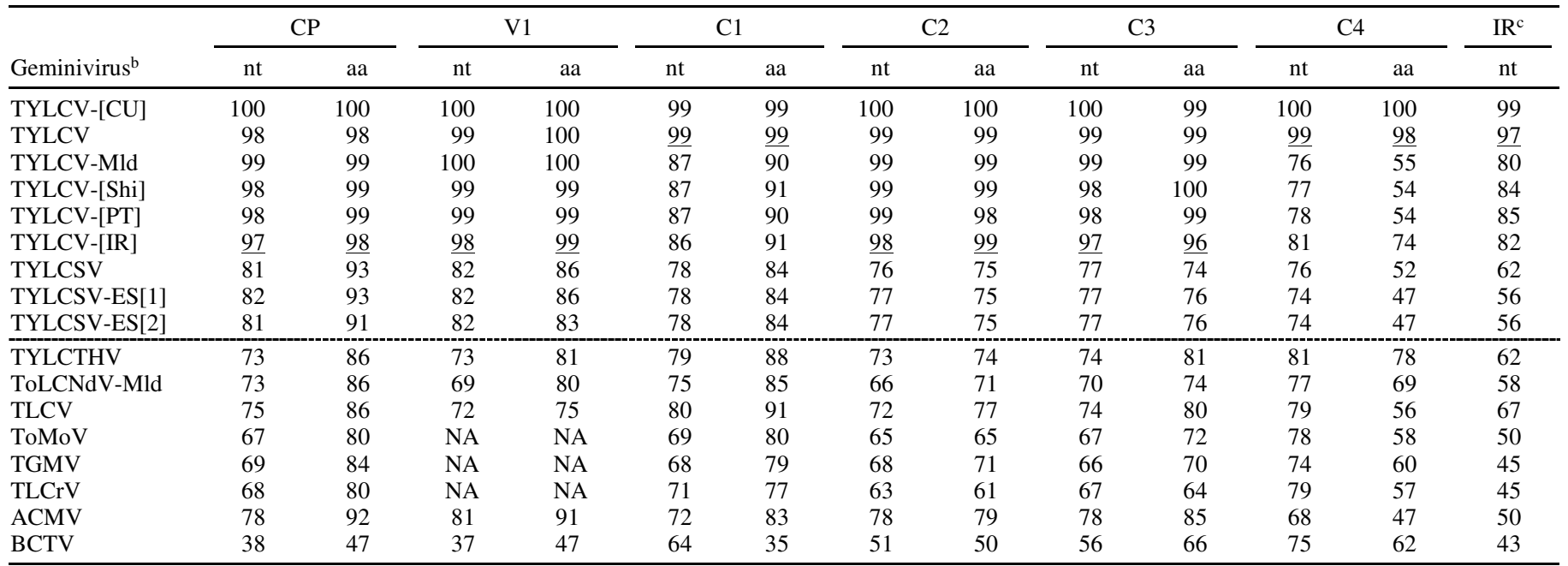

${ }^{a}$ Sequences identical or nearly identical to TYLCV are shown above the solid lines, and monopartite viruses are shown above the dotted line. NA $=$ not applicable; the V1 ORF is not present in the New World bipartite geminiviruses.

b TYLCV, Tomato yellow leaf curl virus; TYLCV-[CU], TYLCV from Cuba; TYLCV-Mld, a mild isolate of TYLCV from Israel; TYLCV-[Shi], a TYLCV isolate from Japan; TYLCV-[PT], a TYLCV isolate from Portugal; TYLCV-[IR], a TYLCV isolate from Iran; TYLCSV, Tomato yellow leaf curl Sardinia virus; TYLCSV-ES[1], a TYLCSV isolate from Murcia, Spain; TYLCSV-ES[2], a TYLCSV isolate from Almeria, Spain; TYLCTHV, Tomato yellow leaf curl Thailand virus; ToLCNdV-Mld, a mild isolate of Tomato leaf curl virus from New Delhi, India; TLCV, Tomato leaf curl virus from Australia; ToMoV, Tomato mottle virus; TGMV, Tomato golden mosaic virus; TLCrV, Tomato leaf crumple virus; ACMV, African cassava mosaic virus; BCTV, Beet curly top virus.

${ }^{c}$ For the bipartite begomoviruses, this is the common region sequence. 
Nucleotide sequence identities between the TYLCV-[DO] ORFs and IR and those of the monopartite TYLCSV isolates from southern Europe, the bipartite TYLCTHV from Thailand, ToLCNdV-Mld from India, and TLCV from Australia ranged from 66 to $91 \%$ (ORFs) and 56 to $67 \%$ (IR) (Table 1). These results are consistent with these tomato-infecting begomoviruses representing distinct viral species (34).

Monitoring the incidence of TYLCV in whiteflies. In response to the TYLCD epidemics of 1992-93, 1993-94, and 1994-95 in the Dominican Republic, a mandatory 3-month whitefly host-free period (including tomato, common bean, cucurbits, eggplant, and pepper) was implemented in 1995 in the northern and southern processing tomato production areas (Fig. 2). To assess the effect of this whitefly host-free period (hereafter referred to as the host-free period) on TYLCV in the Dominican Republic, the incidence of the virus in adult whiteflies in these two areas was monitored during the 1996-97, 1997-98, 1998-99, 1999-2000, and 2000-01 tomato-growing seasons (15 September to 15 May in the north and 1 October to 30 June in the south) and the 1997, 1998, 1999, 2000, and 2001 host-free periods (15 June to 15 September in the north and 30 June to 30 September in the south). The locations where whiteflies were collected are shown in Figure 2. At monthly intervals, approximately 30 adult whiteflies were collected from tomato (during the growing season) or weed or other crop plants (during the host-free period) from each location, placed into test tubes containing alcohol, and shipped to UC Davis. Extracts were prepared from whiteflies and PCR analyses were conducted with the TYLCV CP primer pair (PTYv787 and PTYc1121).

In preliminary experiments conducted in 1996, the $\approx 300$-bp TYLCV CP DNA fragment (hereafter referred to as the CP fragment) was amplified from extracts of all whitefly samples (hereafter referred to as whiteflies) collected from tomato plants during the middle of the growing season (January) when the incidence of TYLCD was high (e.g., 50 to 100\%). In contrast, the $\mathrm{CP}$ fragment was infrequently amplified from whiteflies collected from weeds or other crop plants (mostly illegally planted cucurbits) during the host-free period. To ascertain whether the failure to amplify the CP fragment from some whitefly extracts was due to PCR inhibitors, pTY-DR1 DNA (10 ng) was added into these extracts and the PCR was repeated. The CP fragment was amplified from all such extracts tested, indicating an absence of PCR inhibitors. Southern blot hybridization analysis with the pTY-DR1 probe confirmed the identity of the $\approx 300$-bp PCRamplified CP fragment and established that positive samples could be identified by visual inspection of EtBr-stained agarose gels (i.e., Southern blot hybridization analysis did not reveal additional positive samples). These results suggested that this PCR method could be used to monitor the incidence of TYLCV in whiteflies.

For all five growing seasons and host-free periods in the north (Fig. 3A) and south (Fig. 3B), a similar trend emerged from monitoring of TYLCV in whiteflies. During the host-free period and early in the tomato growing season (September to November), the incidence of TYLCV in whiteflies was relatively low (i.e., the $\mathrm{CP}$ fragment was amplified from few whitefly samples). As the season progressed, the incidence of TYLCV in whiteflies increased until nearly all samples were positive by January or February (Fig. $3 \mathrm{~A}$ and $\mathrm{B})$. As the growing season ended and the harvest of fields was being completed (April to June), the incidence of TYLCV in whiteflies began to decrease. This decrease continued into the host-free period and, by the end of the host-free period, TYLCV was not detected in most whitefly samples (Fig. 3A and B). In most cases, results from EtBr-stained agarose gels and Southern blots were the same, although there were a number of whitefly samples collected during the host-free period where the CP fragment was detected only by Southern blot hybridization analysis.

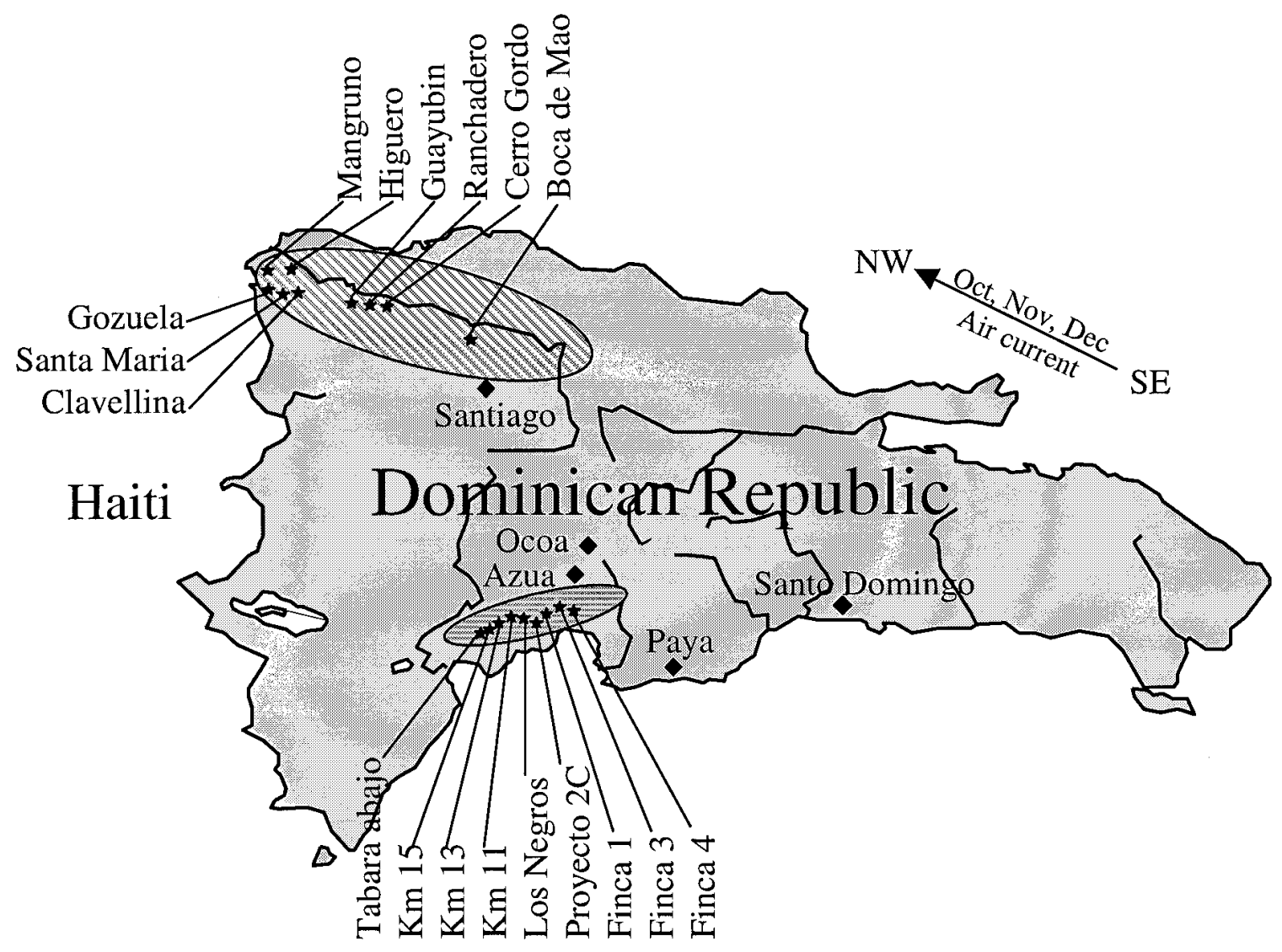

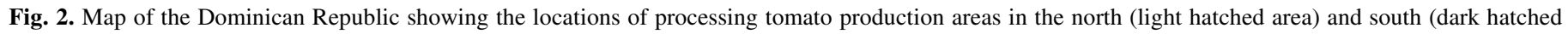
area) and locations from which whiteflies and weed and crop plants were collected for detection of Tomato yellow leaf curl virus. 
The detection of TYLCV in whiteflies reflected the incidence of TYLCD in tomato. During September, October, and November, when the incidence of TYLCV in whiteflies was low in most locations, the incidence of TYLCD in tomato was also low (e.g., 0 to $25 \%$ ). By December, the incidence of TYLCV in whiteflies increased considerably, as did the incidence of TYLCD (e.g., 50 to $100 \%$ ). By January and February, when TYLCV was detected in nearly all whitefly samples, the incidence of TYLCD reached $100 \%$ in many fields.

It is possible that the reduction in TYLCV incidence in whiteflies during the host-free period was due to unfavorable conditions for whiteflies and/or TYLCD development during these months in the Dominican Republic rather than the effect of the host-free period. To test this, TYLCV was monitored in whiteflies collected from around the town of San Jose de Ocoa (Peravia State), an area not subject to the host-free period and where fresh market tomato cultivars are grown throughout the year (Fig. 2). Whiteflies were collected at monthly intervals from tomato fields in two areas, Sabana Larga and Arroyo Palma, beginning in March 2001 and continuing through October 2001. The whiteflies were tested for TYLCV by PCR as previously described. TYLCV was detected in whiteflies collected from both locations in March, April, May, June, July, and October; and from those collected in Sabana Larga, but not Arroyo Palma, in August and September (a new tomato plantation was established at Arroyo Palma in August). Furthermore, TYLCD symptoms were observed in tomato fields at both locations during these months. These results established that TYLCV can infect tomato plants and persist in whiteflies during the months of the host-free period in the Dominican Republic. In contrast, TYLCV was detected less frequently in whiteflies collected over this 8-month-period from the sampling locations in the north and south (i.e., two to four TYLCV-positive samples/location), where the host-free period was in place. An exception was Cerro Gordo in the North, where TYLCV was detected in whiteflies for seven out of eight of these months; however, this was attributed to illegal plantings of tomato during the host-free period at this location.

Taken together, these results established that (i) the host-free period resulted in a reduction in the incidence of TYLCV in the Dominican Republic early in the growing season and (ii) tomato plants play an essential role in the build-up and maintenance of TYLCV early and late in the growing season. Furthermore, detection of TYLCV in whiteflies demonstrated the effectiveness of the host-free period in reducing TYLCV incidence, and may be a useful predictor of the potential for TYLCD development in tomato crops.

Surveys for TYLCV reservoir hosts using squash blot hybridization analysis. To determine where TYLCV-[DO] persisted during the host-free period, surveys of the northern and southern processing tomato production areas were conducted over a 5-year period (January or February 1994 to 1998 and November 1997). Potential TYLCV hosts, such as volunteer and overwintered tomato plants, other crop plants, and weeds, were collected in and around tomato fields (during the growing season) or fields that had tomato production (during the host-free period). During the host-free period, efforts were made to locate and sample illegally
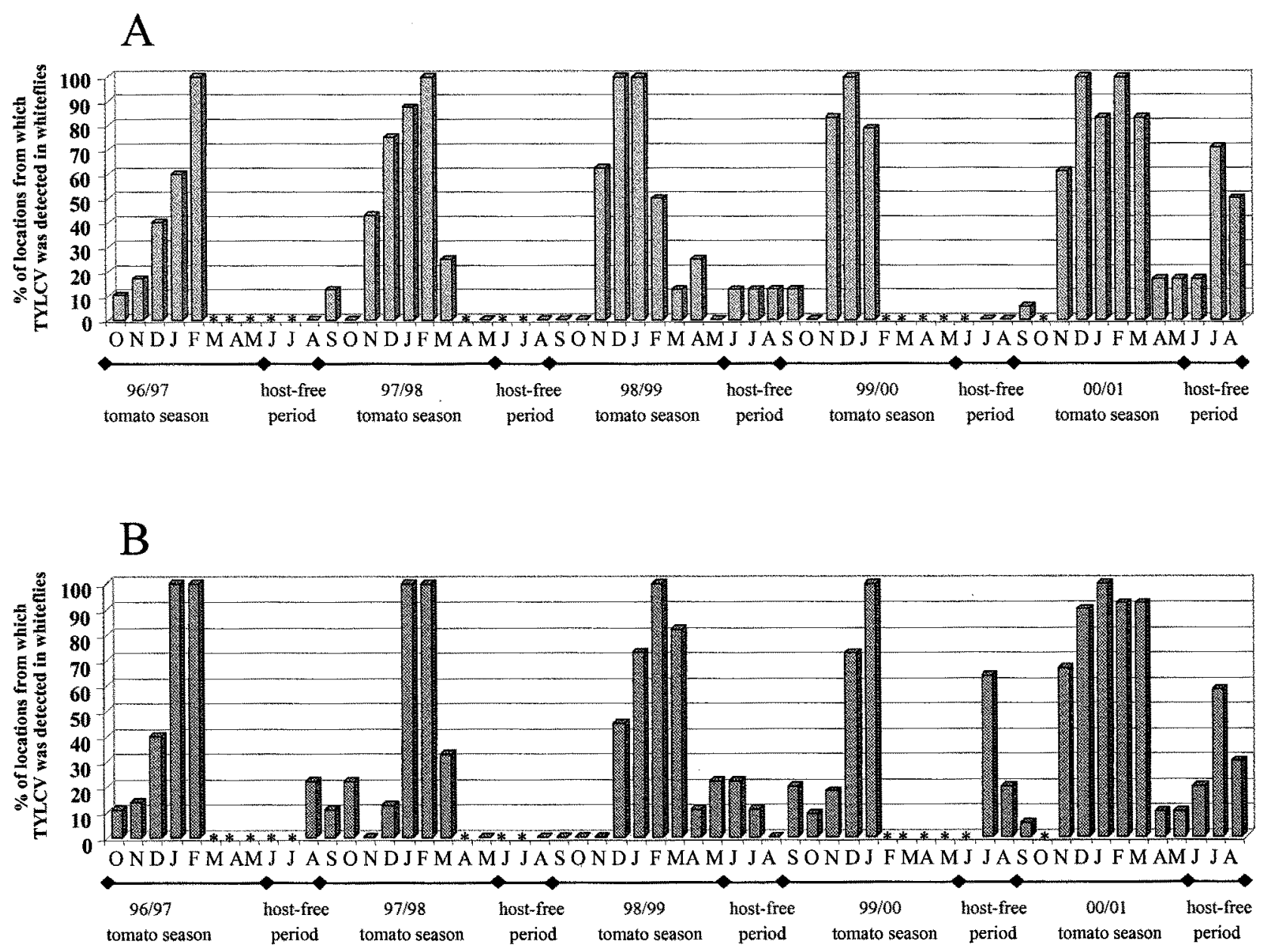

Fig. 3. Percentage of locations (fields) from processing tomato production areas in A, the north and $\mathbf{B}$, the south of the Dominican Republic from which Tomato yellow leaf curl virus (TYLCV) was detected in adult whiteflies. Adult whiteflies $(\approx 30)$ were collected during five tomato growing seasons (1996-97, 1997-98, 1998-99, 1999-2000, and 2000-01) and host-free periods (1997, 1998, 1999, 2000, and 2001). TYLCV was detected in extracts prepared from whiteflies by polymerase chain reaction with a TYLCV coat protein primer pair. Asterisks indicate months in which whiteflies were not sampled. 
grown crops (e.g., tomato, common bean, cucurbits, and peppers). Weeds were usually collected from areas directly bordering fields and 1 to $2 \mathrm{~m}$ from the edge of the field.

During the host-free period, volunteer or illegally planted tomato plants generally were not found. A single overwintered tomato plant was found in Mangruno in the north (Fig. 2), and it had TYLCD symptoms. There also were two locations where illegally planted tomato plants were found. The first was in Paya, a small town to the east of the main processing tomato area in the south (Fig. 2). Here, the host-free period was not enforced and surveys conducted in September 1996, November 1997, September 1998, October 1999, and November 1999 revealed overlapping crops of fresh market tomato, with incidences of TYLCD of $100 \%$ in older fields and 40 to $50 \%$ in younger fields. The second location was Santa Maria in the north (Fig. 2), where unusually high incidences of TYLCD in tomato in November 1997 and 1999 (50 to $100 \%$ ) were attributed to tomato plants that were illegally planted during the host-free period. It was more common to find illegally planted nontomato crops (either in commercial production or in home gardens) such as pepper, common bean, and various cucurbits. Therefore, most of the plants sampled during these surveys were weeds or nontomato crops. Some of the sampled plants (205/572) showed symptoms of virus infection, including distorted and stunted growth and leaf mottling, green to yellow mosaic, yellowing, crumpling, curling, or distortion; whereas the others (267/572) showed no obvious symptoms.

Squash blot hybridization analysis with the TYLCV-[DO] probe revealed strong to very strong hybridization signals (e.g., ratings of 3 to 4) from all tomato plants with TYLCD symptoms. This included the overwintered tomato plant found in Mangruno in November 1997; tomato collected from Paya in September 1996 (two plants), November 1997 (two plants), September 1998 (four plants), October 1999 (five plants), and November 1999 (four plants); and tomato collected from Santa Maria in November 1997

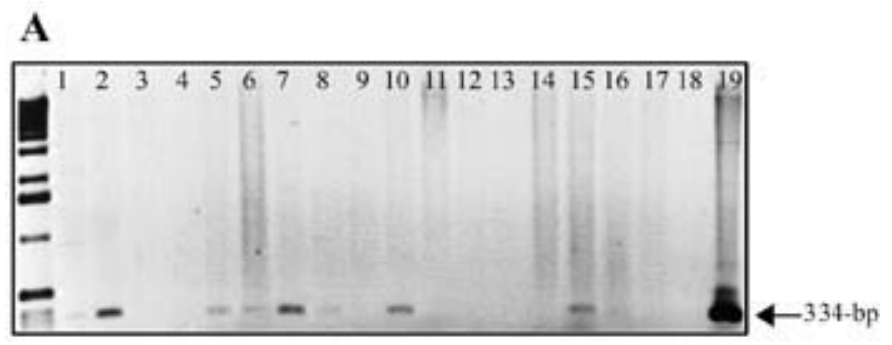

B

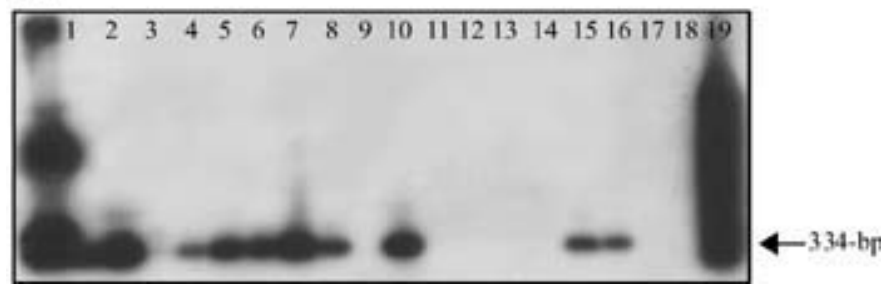

Fig. 4. Detection of Tomato yellow leaf curl virus (TYLCV) from various weeds collected from processing tomato-growing regions of the Dominican Republic in September 2001. A, Agarose gel showing polymerase chain reaction (PCR) products amplified from DNA extracts prepared from various weeds with a TYLCV coat protein $(\mathrm{CP})$ primer pair. B, Southern blot hybridization analysis, with a TYLCV probe, of the agarose gel in (A). Lanes 1 to 12 , symptomless Cleome viscosa plants from three locations; lanes 13 and 14, symptomless Malva spp. plants from a single location; lanes 15 and 16, symptomatic Macroptilium spp. from a single location; and lane 17, a symptomless Macroptilium spp. plant. Lane 18 is negative control (water only) and lane 19 is a positive control, a DNA extract from a TYLCVinfected tomato plant. Arrows indicate the PCR-amplified 334-bp TYLCV CP DNA fragment. (four plants) and 1999 (two plants). In contrast, positive hybridization signals were obtained from only 19 of the 572 nontomato plants. Of these, moderate to strong hybridization signals (ratings of 2 to 4) were obtained for all six Datura stramonium L. plants with TYLC-like symptoms (i.e., interveinal chlorosis and leaf crumpling and curling). In contrast, moderate to strong hybridization signals were obtained from only 3 of 30 pepper plants with symptoms of virus infection, consistent with infection by multiple viruses. Weak to strong hybridization signals (ratings of 1 to 3 ) were detected from 6 of 190 Cleome viscosa L. plants with mild or no symptoms and from 2 of 28 Polygonum spp. with mild or no symptoms. Weak hybridization signals (ratings of 1 to 2 ) were detected from 1 of 33 symptomatic Malva spp. and 1 of 1 symptomless Euphorbia spp., whereas 28 Euphorbia plants with symptoms of virus infection were negative.

Plants from which no hybridization signals were detected included common bean (five plants with mosaic, mottle, or leaf curling), tobacco (20 plants with mosaic or mottle symptoms), Croton lobatus L. (12 plants with mild or no symptoms), and Solanum nigrum (3 plants with no symptoms). Consistent with results of a previous study (26), the TYLCV probe did not hybridize with squash blots of weed (e.g., Jatropha spp., Sida spp., Malva spp., and Euphorbia spp.) or common bean plants with golden mosaic symptoms. However, when equivalent squash blots were hybridized with a general begomovirus probe (15), moderate to strong hybridization signals (ratings of 2 to 4) were detected (data not shown). These results indicate that the golden mosaic symptoms in these plants were induced by begomoviruses other than TYLCV-[DO].

Surveys for TYLCV reservoir hosts with PCR and Southern blot hybridization analyses. To further assess the potential of various weed and crop plants to serve as TYLCV reservoir hosts, PCR with the TYLCV CP primers was used. First, the specificity of these primers was assessed by testing whether they would direct the amplification of DNA fragments from extracts prepared from plants infected with the following begomoviruses: Bean dwarf mosaic virus, Bean golden yellow mosaic virus, Pepper huasteco virus (PHV), Squash leaf curl virus, TLCrV, and ToMoV. The TYLCV CP primers failed to direct the amplification of DNA fragments from any of these extracts, whereas the expected-sized fragments were amplified from these extracts with the degenerate primer pair PAL1v1978 and PAR1c496 (43) or, for PHV, primer pair PAL1c2329 and PAL1v1471 (12). These results suggested that the TYLCV CP primers are TYLCV-specific.

Leaf samples were collected from weeds and nontomato crops with or without symptoms in October 1998 (249 samples), January 1999 (284 samples), October 1999 (160 samples), January 2000 (80 samples), and September 2001 (57 samples) from the same locations sampled for the squash blot hybridization analyses. In the January and October 1999, January 2000, and September 2001 surveys, emphasis was placed on hosts in which TYLCV was detected in the October 1998 survey. DNA extracts were prepared from leaf tissue from each plant, and PCR was performed with the TYLCV CP primers. PCR products were analyzed by agarose gel electrophoresis and Southern blot hybridization analysis with the pTY-DR1 probe.

In preliminary experiments conducted in 1998, the CP fragment was not amplified from any samples when 10 to $20 \mu \mathrm{l}$ of DNA extract was used in the PCR. However, when $50 \mu \mathrm{l}$ of DNA extract was used, an $\approx 300$-bp DNA fragment was amplified from a number of samples (Fig. 4A). Southern blot hybridization analyses confirmed that this was the $\mathrm{CP}$ fragment, and revealed the presence of the CP fragment from other samples (Fig. 4B). In the October 1998 survey, the most common weed species from which the $\mathrm{CP}$ fragment was amplified were Cleome viscosa (Caparidaceae), Croton lobatus (Euphorbiaceae), Malva spp. (Malvaceae), and Solanum nigrum (Solanaceae) (Table 2). Importantly, nearly all of these were symptomless. In the January 1999 
survey, the CP fragment was amplified from symptomless plants of these same weed species (e.g., Cleome viscosa, Croton lobatus, Malva spp., and $S$. nigrum), as well as from Physalis spp. (Solanaceae) with mild or no symptoms. Furthermore, the CP fragment was amplified from more of these weeds than in the October survey (Table 2). The CP fragment also was amplified from common bean (with mosaic or mottle symptoms) and pepper plants (with leaf curl and distortion or no obvious symptoms) collected from fields that were adjacent to tomato fields with very high incidences of TYLCD. Similar results were obtained for the October 1999, January 2000, and September 2001 surveys, with the CP fragment amplified from symptomless weeds such as Cleome viscosa, Croton lobatus, and S. nigrum (Table 2). In the January 2000 survey, the CP fragment also was amplified from pepper plants with leaf curl and distortion symptoms collected from a field adjacent to tomato fields with high incidences of TYLCD. Together, these results suggest that (i) symptomless TYLCV infections can occur in a number of weed species and (ii) common bean and pepper can be infected with TYLCV in the Dominican Republic.

\section{DISCUSSION}

Analysis of the TYLCV-[DO] sequence provides definitive evidence for introduction of the virus from the eastern Mediter- ranean. The nucleotide sequence of TYLCV-[DO] is nearly identical to that of TYLCV, indicating that TYLCV-[DO] is an isolate of TYLCV and providing further evidence that TYLCV was introduced into the Caribbean from the eastern Mediterranean. This is fully consistent with previous reports, and expands on the partial characterization of the virus presented in these reports $(26,38)$. The importance of determining the complete sequence of a TYLCV isolate was revealed by the results of the sequence analyses in which a number of TYLCV isolates (e.g., TYLCV-Mld, TYLCV-[PT], TYLCV-[Shi], and TYLCV-[IR]) were found to be recombinant viruses. A similar finding was recently reported (29) and, together, these findings suggest that recombination between TYLCV and other begomoviruses can lead to the evolution of new TYLCV strains or begomoviruses. Therefore, knowing the precise identity of a TYLCV isolate in a given region has important practical considerations in terms of selecting or developing appropriate detection methods or resistant cultivars.

The TYLCV-[DO] sequence was more identical to that of TYLCV-[CU] (>99\% identity) than to that of TYLCV (>97\% identity). These results are consistent with an initial introduction of TYLCV into the Caribbean followed by sequence divergence (from TYLCV) and dissemination to other countries of the Caribbean Basin. The means by which TYLCV was introduced into the Dominican Republic is not known, although it probably did not

TABLE 2. Detection of Tomato yellow leaf curl virus (TYLCV) in weeds and crop plants sampled in the Dominican Republic ${ }^{\text {a }}$

\begin{tabular}{|c|c|c|c|c|c|}
\hline Plant family, species & October 1998 & January 1999 & October 1999 & January 2000 & September 2001 \\
\hline \multicolumn{6}{|l|}{ Acanthaceae } \\
\hline Unidentified & $1(1)$ & $\ldots$ & $\ldots$ & $\ldots$ & $\ldots$ \\
\hline \multicolumn{6}{|l|}{ Caparidaceae } \\
\hline Cleome viscosa & $6(63)$ & $57(104)$ & $2(66)$ & $14(32)$ & $17(34)$ \\
\hline \multicolumn{6}{|l|}{ Compositeae } \\
\hline Ambrosia elation & $0(4)$ & $\ldots$ & $\ldots$ & $\ldots$ & $\ldots$ \\
\hline Unidentified & $0(4)$ & $\ldots$ & $\ldots$ & $\ldots$ & $\ldots$ \\
\hline \multicolumn{6}{|l|}{ Cucurbitaceae } \\
\hline Unidentified & $0(5)$ & $\ldots$ & $1(9)$ & $\ldots$ & $\ldots$ \\
\hline \multicolumn{6}{|l|}{ Cyanastraceae } \\
\hline Zebrina spp. & $0(4)$ & $\ldots$ & $\ldots$ & $\ldots$ & $\ldots$ \\
\hline \multicolumn{6}{|l|}{ Euphorbiaceae } \\
\hline Croton lobatus & $5(9)$ & $38(54)$ & $5(34)$ & $12(14)$ & $1(3)$ \\
\hline Euphorbia spp. & $0(9)$ & $1(9)$ & $\ldots$ & $1(3)$ & $0(4)$ \\
\hline Manihot esculenta & $0(1)$ & $\ldots$ & $\ldots$ & $\ldots$ & $\ldots$ \\
\hline \multicolumn{6}{|l|}{ Leguminosae-Papilionoideae } \\
\hline Calopogonium spp. & $0(2)$ & $1(2)$ & $\ldots$ & $\ldots$ & $0(1)$ \\
\hline Macroptilium spp. & $1(2)$ & $1(3)$ & $0(3)$ & $\ldots$ & $2(3)$ \\
\hline Vigna unguiculata & $\ldots$ & $\ldots$ & $0(1)$ & $\ldots$ & $\ldots$ \\
\hline Phaseolus vulgaris & $\ldots$ & $5(5)$ & $0(1)$ & $\ldots$ & $\ldots$ \\
\hline Unidentified & $6(23)$ & $4(11)$ & $1(4)$ & $3(6)$ & $2(2)$ \\
\hline \multicolumn{6}{|l|}{ Malvaceae } \\
\hline Abelmoschus esculentum & $0(2)$ & $\ldots$ & $\ldots$ & $0(1)$ & $\ldots$ \\
\hline Bastardia spp. & $0(10)$ & $\ldots$ & $\ldots$ & $\ldots$ & $\ldots$ \\
\hline Malva spp. & $11(32)$ & $5(24)$ & $1(7)$ & $\ldots$ & $4(8)$ \\
\hline Sida spp. & 0 (12) & $3(11)$ & $3(29)$ & $\ldots$ & $\ldots$ \\
\hline Wissadula spp. & $3(3)$ & $1(10)$ & $\ldots$ & $\ldots$ & $\ldots$ \\
\hline \multicolumn{6}{|l|}{ Nyctaginaceae } \\
\hline Unidentified & $2(2)$ & $\ldots$ & $\ldots$ & $\ldots$ & $\ldots$ \\
\hline \multicolumn{6}{|l|}{ Solanaceae } \\
\hline Capsicum annuит & $1(1)$ & $16(19)$ & $\ldots$ & $6(6)$ & $\ldots$ \\
\hline Datura stramonium & $0(1)$ & $\ldots$ & $\ldots$ & $\ldots$ & $\ldots$ \\
\hline Physalis spp. & $\ldots$ & $5(12)$ & $0(1)$ & $1(1)$ & $\ldots$ \\
\hline \multicolumn{6}{|l|}{ Solanum melongena } \\
\hline var. esculentum & $0(3)$ & $\ldots$ & $\ldots$ & $\ldots$ & $\ldots$ \\
\hline Solanum nigrum & $5(7)$ & $3(12)$ & $1(2)$ & $11(12)$ & $1(1)$ \\
\hline Unidentified weed & $2(49)$ & $4(8)$ & $0(4)$ & $0(1)$ & $0(1)$ \\
\hline Total & $43(249)$ & $144(284)$ & $14(161)$ & $48(80)$ & $27(57)$ \\
\hline \multicolumn{6}{|l|}{ Controls } \\
\hline TYLCV-infected tomato & $15(15)$ & $18(18)$ & $12(12)$ & $7(7)$ & $4(4)$ \\
\hline Healthy tomato & $0(15)$ & $0(10)$ & $0(12)$ & $0(7)$ & $0(4)$ \\
\hline
\end{tabular}

${ }^{\bar{a}}$ Results are presented as number of samples testing positive for TYLCV out of the total number of samples assayed (in parentheses). A sample was determined positive based on detection (either visually or by Southern blot hybridization analysis with a TYLCV probe) of a polymerase chain reaction-amplified TYLCV coat protein DNA fragment. 
occur through seed because TYLCV is not seed transmitted. TYLCV could have been introduced via tomato transplants (37, 39), symptomatic (e.g., lisianthus [6]) or symptomless hosts, or whiteflies. A recent report showing transovarial transmission of TYLCV in B. tabaci (13) increases the possibility of long-distance dissemination in the insect vector. Regardless, the rapid spread of TYLCV throughout the Caribbean Basin $(4,22,26,41,47)$ and into Mexico (2), the southern United States $(24,39,49)$, and Spain (48), demonstrates a remarkable capacity for long-distance dissemination. Clearly, it is important to carefully regulate the movement of plant materials from areas having TYLCV in order to avoid the inadvertent introduction of the virus into TYLCV-free tomatogrowing regions.

Monitoring of TYLCV in whiteflies reveals a dramatic decrease in TYLCV during the host-free period. The implementation of a mandatory 3-month host-free period is considered to be responsible, in great part, for the recovery of the processing tomato industry in the Dominican Republic from the devastating losses caused by TYLCV (16). The effectiveness of this host-free period, in terms of reducing the incidence of TYLCV, was revealed by monthly monitoring of the virus in whiteflies. Whereas TYLCV was detected in most whitefly samples (collected from tomato) by the middle of the tomato-growing season (December to January), it was detected in relatively few samples (collected from weeds and cucurbits) during the host-free period. Taken together with the finding that the incidence of TYLCV remained high in whiteflies and tomato plants during the months of the host-free period in an area not subject to the host-free period (San Jose de Ocoa), these results suggest that the host-free period results in a marked decrease in TYLCV inoculum in the Dominican Republic. This decrease may also be aided by the concomitant decrease in the whitefly population during this period. Monitoring of TYLCV in whiteflies also revealed a low incidence of TYLCV up to 8 weeks after planting of the new tomato crop. This lag period allows tomato plants time to produce flowers and set fruit, thereby allowing for acceptable yields despite high incidences of TYLCV later in the growing season.

The effectiveness of the host-free period for TYLCV management in the Dominican Republic is consistent with results from other areas. For example, in Mediterranean countries where TYLCV has been established for decades, it is well established that the most important inoculum source for newly planted tomato is old, established fields or volunteer tomato plants $(5,19,25,31)$. In Cyprus, the incidence of TYLCV in tomato was greatly reduced in a geographically isolated area where old and volunteer tomato plants were carefully rogued compared with surrounding areas in which traditional production (i.e., overlapping tomato crops) was practiced (19). In the Dominican Republic, the importance of utilizing a whitefly host-free period rather than a tomatofree period was demonstrated by the detection of TYLCV in pepper and common bean plants. TYLCV also has been reported to infect pepper in Jamaica and Spain $(42,45)$ and common bean in Spain (28). Although the importance of these hosts in the epidemiology of TYLCV in the Dominican Republic was not determined, these crops could serve as TYLCV inoculum sources in the absence of tomato and should be included in the host-free period. However, an analysis of vector feeding habits should be conducted to verify that whiteflies feed on and transmit TYLCV from infected pepper and common bean plants.

TYLCV may survive in symptomless hosts during the hostfree period. TYLCV reappears in tomato fields following the host-free period, indicating that the virus persists in the absence of tomato. Possible means by which TYLCV could persist include (i) volunteer, overwintered, or illegally planted tomato; (ii) reservoirs hosts; and (iii) the whitefly vector. Volunteer, overwintered, or illegally planted tomato plants were rarely found during the hostfree period but, when identified, they were heavily infected by TYLCV (e.g., $>50 \%$ disease incidence). Thus, these hosts could serve as viral inoculum sources, but their infrequent and localized occurrence suggested that they were not the primary inoculum source. The absence of volunteer and overwintered tomato was attributed to (i) plowing of old tomato fields after harvest and replanting with non-whitefly host crops such as sorghum, and (ii) the hot, dry conditions in fallow fields during the host-free period. The absence of illegally planted tomato was attributed to government enforcement of the host-free period and a vigorous grower education program undertaken by the Ministry of Agriculture and the processing tomato industry.

Surveys for TYLCV reservoir hosts revealed that few plant species in or around tomato fields showed typical TYLCV symptoms (i.e., leaves with upcurling, crumpling, or interveinal chlorosis). D. stramonium is a known host of TYLCV $(5,26,31)$, and symptomatic TYLCV-infected D. stramonium plants were found in the Dominican Republic in 1994 and 2000. However, the sporadic distribution of the this host makes it unlikely to be a major primary inoculum source. Symptomless TYLCV infections were detected in a number of common weed species, including some previously reported as hosts of TYLCV (e.g., Malva parviflora L. [7]) or TYLCSV (e.g., S. nigrum L. [3]), and some that represent newly reported hosts for TYLCV (e.g., Cleome viscosa, Croton lobatus, and Physalis spp.). Members of the family Caparidaceae (e.g., Cleome viscosa) have not been previously reported as hosts of TYLCV.

The viral titer in the symptomless weeds infected by TYLCV was very low, based on the need to use a large quantity of DNA extract in the PCR or Southern blot hybridization analyses to detect the PCR-amplified TYLCV CP fragment. Bipartite begomovirus infections in hosts to which the viruses are not well adapted are characterized by mild or no symptoms, low infection rates, and low levels of viral DNA $(18,36,40)$. Thus, it appears that TYLCV is not well adapted to these weed hosts. However, given the perennial nature, wide distribution, and high populations of some of these weeds in the Dominican Republic (e.g., Cleome viscosa and Croton lobatus), they may be important primary TYLCV inoculum sources, particularly early in the tomato season. Moreover, once TYLCV is introduced into an area, these weeds are likely to be permanent reservoirs of the virus. A survey for reservoir hosts of BCTV in California, using dot blot hybridization, revealed symptomless infections in weed hosts at infection rates of 2 to $11 \%$ (8). Symptomless hosts may be important inoculum sources for other geminiviruses, which may explain why it has been difficult to identify reservoir hosts for many cropinfecting geminiviruses. Thus, surveys for symptomless reservoir hosts could provide important information regarding the epidemiology of other geminivirus-induced diseases.

It will be important to establish the efficiency with which whiteflies can acquire TYLCV (or other geminiviruses) from symptomless hosts. The fact that these hosts are infected by TYLCV indicates that, at least, whiteflies fed on and transmitted the virus to these plants. A second question is the frequency with which whiteflies move from weed hosts to tomato. The 4- to 8-week lag period before TYLCV builds up in the tomato crop after the host-free period suggests that acquisition or transfer of TYLCV from symptomless hosts is inefficient. This may be due to (i) the low amount of virus present in these hosts, (ii) the low incidence of infection, (iii) the low populations of whiteflies existing on these hosts during the host-free period, or (iv) low rates of whitefly immigration from weeds to tomato.

Another possible means for TYLCV to persist during the hostfree period is in the whitefly vector. However, the fact that the incidence of TYLCV in whiteflies decreased considerably during the host-free period suggests that the virus does not persist efficiently in the insect in the absence of TYLCV-infected tomato. This is likely due to (i) the loss of the virus during the multiple generations of whiteflies that would occur during the 3-month host-free period, (ii) low rates of transovarial transmission (13), or 
(iii) the pathogenic effect of TYLCV on whitefly biology (46). Nevertheless, whiteflies represent a potential TYLCV inoculum source, and this is another reason to impose a whitefly host-free period rather than a tomato-free period.

TYLCV appears to be permanently established in the Dominican Republic; therefore, it will be important to continue the hostfree period for effective disease management. Although this causes some hardship for small farmers by limiting their ability to grow certain crops, non-whitefly hosts such as onion, garlic, sorghum, corn, and cassava (not a preferred whitefly host in the Dominican Republic) still can be grown. The use of insecticides, such as the systemic neonicotinoids (e.g., imidacloprid), has allowed for improved whitefly control and a reduction in the spread of TYLCV during the tomato-growing season. The use of TYLCV-resistant tomato cultivars, developed by traditional breeding or biotechnology methods, is the most desirable long-term management strategy. A number of resistant or tolerant cultivars are now commercially available and are presently used in late plantings, when TYLCV incidence is high. Development of new TYLCV-resistant cultivars with improved horticultural traits could, theoretically, eliminate the need for the host-free period. However, at this time, continued effective management of TYLCV in the Dominican Republic will require an integrated strategy involving farmers, industry, and government personnel.

\section{ACKNOWLEDGMENTS}

This research was supported by grant 96-34339-3511 from the United States-Israel Binational Agricultural Research and Development Fund (BARD) to R. L. Gilbertson, a grant from the USAID Bean/Cowpea CRSP to D. P. Maxwell, and a fellowship from the Conselho Nacional de Pesquisa (CNPq)-Brazil to R. Salati. We thank Transagricola S. A., Navarette, Dominican Republic, and Ing. M. Sanchez for their support and assistance.

\section{LITERATURE CITED}

1. Antignus, E. Y., and Cohen, S. 1994. Complete nucleotide sequence of an infectious clone of a mild isolate of tomato yellow leaf curl virus (TYLCV). Phytopathology 84:707-712.

2. Ascencio-Ibanez, J. T., Diaz-Plaza, R., Mendez-Lozano, J., MonsalveFonnegra, Z. I., Arguello-Astorga, G. R., and Rivera-Bustamante, R. F. 1999. First report of tomato yellow leaf curl geminivirus in Yucatan. Plant Dis. 83:1178.

3. Bedford, I. D., Kelly, A., Banks, G. K., Briddon, R. W., Cenis, J. L., and Markham, P. G. 1999. Solanum nigrum: An indigenous weed reservoir for a tomato yellow leaf curl geminivirus in Southern Spain. Eur. J. Plant Pathol. 104:221-222.

4. Bird, J., Idris, A. M., Rogan, D., and Brown, J. K. 2001. Introduction of the exotic Tomato yellow leaf curl virus-Israel in tomato in Puerto Rico. Plant Dis. 85:1028.

5. Cohen, S., and Antignus, Y. 1994. Tomato yellow leaf curl virus, a whitefly-borne geminivirus of tomatoes. Adv. Dis. Vector Res. 10:259-288.

6. Cohen, J., Gera, A., Ecker, R., Ben Joseph, R., Perlsman, M., Gokkers, M., Lachman, O., and Antignus, Y. 1995. Lisianthus leaf curl a new disease of lisianthus caused by tomato yellow leaf curl virus. Plant Dis. 79:416-420.

7. Cohen, S., Kern, J., Harpz, I., and Ben-Joseph, R. 1988. Epidemiological studies of the tomato yellow leaf curl virus (TYLCV) in the Jordan Valley, Israel. Phytoparasitica 16:259-270.

8. Creamer, R., Luque-Williams, M., and Howo, M. 1996. Epidemiology and incidence of beet curly top geminivirus in naturally infected weed hosts. Plant Dis. 80:533-535.

9. Dellaporta, S. L., Wood, J., and Hicks, J. B. 1983. A plant DNA minipreparation: Version II. Plant Mol. Biol. 1:19-21.

10. Devereux, J., Haeberli, P., and Smithies, G. 1984. A comprehensive set of sequence analysis programs for the VAX. Nucleic Acids Res. 12:387395.

11. Faria, J. C., Gilbertson, R. L., Hanson, S. F., Morales, F. J., Ahlquist, P., Loniello, A. O., and Maxwell, D. P. 1994. Bean golden mosaic geminivirus type II isolates from the Dominican Republic and Guatemala: Nucleotide sequences, infectious pseudorecombinants, and phylogenetic relationships. Phytopathology 84:321-329.

12. Garrido-Ramirez, E. R., and Gilbertson, R. L. 1998. First report of tomato mottle geminivirus infecting tomatoes in Yucatan, Mexico. Plant Dis. 82:592.

13. Ghanin, M., Morin, S., Zeiden, M., and Czosnek, H. 1998. Evidence of transovarial transmission of tomato yellow leaf curl virus by its vector, the whitefly Bemisia tabaci. Virology 240:295-303.

14. Gilbertson, R. L., Faria, J. C., Hanson, S. F., Morales, F., Ahlquist, P., Maxwell, D. P., and Russell, D. R. 1991. Cloning of the complete DNA genomes of four bean-infecting geminiviruses and determining their infectivity by electric discharge particle acceleration. Phytopathology 81:980-985.

15. Gilbertson, R. L., Hidayat, S. H., Martinez, R. T., Leong, S. A., Faria, J. C., Morales, F., and Maxwell, D. P. 1991. Differentiation of beaninfecting geminiviruses by nucleic acid hybridization probes and aspects of bean golden mosaic in Brazil. Plant Dis. 75:336-342.

16. Gilbertson, R. L., Ullman, D. E., Salati, R., Maxwell, D. P., GraftonCardwell, E. E., and Polek, M. 1998. Insect-transmitted viruses threaten agriculture. Calif. Agric. 52:23-28.

17. Hanley-Bowdoin, L., Settlage, S. B., Orozco, B. M., Nagar, S., and Robertson, D. 1999. Geminiviruses: Models for plant DNA replication, transcription, and cell cycle regulation. Crit. Rev. Plant Sci. 18:71-106.

18. Hou Y.-M., Paplomatas, E. J., and Gilbertson, R. L. 1998. Host adaptation and replication properties of two bipartite geminiviruses and their pseudorecombinants. Mol. Plant-Microbe Interact. 11:208-217.

19. Ioannou, N. 1987. Cultural management of tomato yellow leaf curl disease in Cyprus. Plant Pathol. 36:367-373.

20. Kheyr-Pour, A., Bendhmane, M., Matzeit, V., Accoto, G. P., Crespi, S., and Gronenborn, B. 1991. Tomato yellow leaf curl virus from Sardinia is a whitefly transmitted monopartite geminivirus. Nucleic Acids Res. 24:6763-6769

21. Laufs, J., Traut, W., Heyraud, F., Matzeit, V., Rogers, S. G., Schell, J., and Gronenborn, B. 1995. In vitro cleavage and joining at the viral origin of replication by the replication initiator protein of tomato yellow leaf curl virus. Proc. Natl. Acad. Sci. USA 92:3879-3883.

22. MacGlashan, D., Polston, J. E., and Bois, D. 1994. Tomato yellow leaf curl geminivirus in Jamaica. Plant Dis. 78:1219.

23. Mehta, P., Wyman, J. A., Nakhla, M. K., and Maxwell, D. P. 1994. Polymerase chain reaction detection of viruliferous Bemisia tabaci (Homoptera: Aleyrodidae) with two tomato-infecting geminivirus. J. Econ. Entomol. 87:1285-1290.

24. Momol, M. T., Simone, G. W., Dankers, W., Sprenkel, R. K., Olson, S. M., Momol, E. A., Polston, J. E., and Hiebert, E. 1999. First report of tomato yellow leaf curl virus in tomato in South Georgia. Plant Dis. 83:487.

25. Nakhla, M. K., and Maxwell, D. P. 1999. Epidemiology and management of tomato yellow leaf curl disease. Pages 565-583 in: Plant Virus Disease Control. A. Hadidi, R. K. Khetarpal, and H. Koganezawa, eds. The American Phytopathological Society, St. Paul, MN.

26. Nakhla, M. K., Maxwell, D. P., Martinez, R. T., Carvalho, M. G., and Gilbertson, R. L. 1994. Widespread occurrence of the eastern Mediterranean strain of tomato yellow leaf curl geminivirus in tomatoes in the Dominican Republic. Plant Dis. 78:926.

27. Nakhla, M. K., Mazyad, H. M., and Maxwell, D. P. 1993. Molecular characterization of four tomato yellow leaf curl virus isolates from Egypt and development of diagnostic methods. Phytopathol. Mediterr. 32:163173.

28. Navas-Castillo, J., Sanchez-Campos, S., Diaz, J. A., Saez-Alonso, E., and Moriones, E. 1999. Tomato yellow leaf curl virus-Is causes a novel disease of common bean and severe epidemics in tomato in Spain. Plant Dis. 83:29-32.

29. Navas-Castillo, J., Sanchez-Campos, S., Noris, E., Louro, D., Accotto, G. P., and Moriones, E. 2000. Natural recombination between Tomato yellow leaf curl virus-Is and Tomato leaf curl virus. J. Gen. Virol. 81:2797-2801.

30. Navot, N., Picherski, E., Zeidan, M., Zamir, D., and Czosnek, H. 1991. Tomato yellow leaf curl virus: A whitefly-transmitted geminivirus with a single genomic molecule. Virology 185:151-161.

31. Nitzany, F. E. 1975. Tomato yellow leaf curl virus. Phytopathol. Mediterr. 14:127-129.

32. Noris, E., Hidalgo, E., Accotto, G. P., and Moriones, E. 1994. High similarity among the tomato yellow leaf curl virus from the west Mediterranean basin: The nucleotide sequence of an infectious clone from Spain. Arch. Virol. 135:165-170.

33. Noris, E., Vaira, A. M., Caciagli, P., Masenga, V., Gronenborn, B., and Accotto, G. P. 1998. Amino acids in the capsid protein of Tomato yellow leaf curl virus that are crucial for systemic infection, particle formation, and insect transmission. J. Virol. 72:10050-10057.

34. Padidam, M., Beachy, R. N., and Fauquet, C. M. 1995. Tomato leaf curl geminivirus from India has a bipartite genome and coat protein is not essential for infectivity. J. Gen. Virol. 76:25-35.

35. Patel, V. P., Rojas, M. R., Paplomatas, E. J., and Gilbertson, R. L. 1993. 
Cloning biologically active geminivirus DNA using PCR and overlapping primers. Nucleic Acids Res. 21:1325-1326.

36. Petty, I. T. D., Miller, C. G., Meade-Hash, T. J., and Schaffer, R. L. 1995. Complementable and noncomplementable host adaptation defects in bipartite geminiviruses. Virology 212:263-267.

37. Polston, J. E., and Anderson, P. 1997. The emergence of whiteflytransmitted geminiviruses in tomato in the Western Hemisphere. Plant Dis. 81:1358-1369.

38. Polston, J. E., Bois, D., Serra, C.-A., and Concepcion, S. 1994. First report of a tomato yellow leaf curl-like geminivirus in the Western Hemisphere. Plant Dis. 78:831.

39. Polston, J., McGovern, R. J., and Brown, L. G. 1999. Introduction of tomato yellow leaf curl virus in Florida and implications for the spread of this and other geminiviruses of tomato. Plant Dis. 83:984-988.

40. Pooma, W., Gillette, W. K., Jeffrey, J. L., and Petty, I. T. D. 1996. Host and viral factors determine the dispensability of coat protein for bipartite geminivirus systemic movement. Virology 218:264-268.

41. Ramos, P. L., Guerra, O., Dorestes, V., Ramirez, N., Rivera-Bustamante, R., and Oramas, P. 1996. Detection of TYLCV in Cuba. Plant Dis. 80:1208.

42. Reina, J., Morilla, G., Bejarano, E. R., Rodriguez, M. D., and Janssen, D. 1999. First report of Capsicum annuum plants infected by tomato yellow leaf curl virus. Plant Dis. 83:1176.

43. Rojas, M. R., Gilbertson, R. L., Russell, D. R., and Maxwell, D. P. 1993.
Use of degenerate primers in the polymerase chain reaction to detect whitefly-transmitted geminiviruses. Plant Dis. 77:340-347.

44. Rojas, M. R., Jiang, H., Salati, R., Xoconostle-Cazares, B., Sudarshana, M. R., Lucas, W. J., and Gilbertson, R. L. 2001. Functional analysis of proteins involved in movement of the monopartite begomovirus, Tomato yellow leaf curl virus. Virology 291:110-125.

45. Roye, M. E., Wernecke, M. E., McLaughlin, W. A., Nakhla, M. K., and Maxwell, D. P. 1999. Tomato dwarf leaf curl virus, a new bipartite geminivirus associated with tomatoes and peppers in Jamaica and mixed infection with tomato yellow leaf curl virus. Plant Pathol. 48:370-378.

46. Rubistein, G., and Czosnek, H. 1997. Long-term association of tomato yellow leaf curl virus with its whitefly vector Bemisia tabaci: Effect on the insect transmission capacity, longevity and fecundity. J. Gen. Virol. 78:2683-2689.

47. Sinisterra, X., Patte, C. P., Siewnath, S., and Polston, J. E. 2000. Identification of Tomato yellow leaf curl virus-Is in The Bahamas. Plant Dis. 84:592.

48. Sanchez-Campos, S., Navas-Castillo, J., Camero, R., Soria, C., Diaz, J. A., and Moriones, E. 1999. Displacement of tomato yellow leaf curl virus (TYLCV)-Sr by TYLCV-Is in tomato epidemics in Spain. Phytopathology 89:1038-1043.

49. Valverde, R. A., Lotrakul, P., Landry, A. D., and Boudreaux, J. E. 2001. First report of Tomato yellow leaf curl virus in Louisiana. Plant Dis. $85: 230$. 